\author{
반추위 섬유소분해 박테리아 배양액의 투여 수준에 따른 한우 반추위 \\ 발효에 미치는 영향 \\ 박중국*·정찬성** · 박도연*·김현철*·이승철** · 김창현*** \\ 한경대학교 생물환경·정보통신전문대학원*, 경기도 축산위생연구소**, \\ 한경대학교 동물생명환경과학부***
}

\title{
Effects of Increasing Inclusion Levels of Rumen Cellulolytic Bacteria Culture on In vivo Ruminal Fermentation Patterns in Hanwoo Heifers
}

\author{
Joong Kook Park*, Chan Sung Jeong**, Do Yeun Park*, Hyun Cheol Kim*, Seung Cheol Lee** \\ and Chang-Hyun Kim*** \\ Graduate School of Bio-Environment and Information Technology, Hankyong National University*, \\ Gyeonggi Livestock Veterinary Research Institute**, \\ School of Animal Life and Environment Science, Hankyong National University***
}

\begin{abstract}
This experiment was conducted to observe the effects of anaerobic cellulolytic bacteria culture (Ruminococcus flavefaciens $\mathrm{H}-20$ and Fibrobactor succinogenes $\mathrm{H}-23$ ) on in vivo ruminal fermentation characteristics in Hanwoo heifers. Four ruminally cannulated Hanwoo heifers $(221 \pm 7.5 \mathrm{~kg})$ receiving a basal diet containing $3 \mathrm{~kg}$ of mixture hay (tall fescue and ochardgrass) and $2 \mathrm{~kg}$ of concentrate per day were in a $4 \times 4$ Latin square with 21 -day periods. Treatments were the basal diet without the culture additive (control), the basal diet plus $50 \mathrm{ml} /$ day of bacteria culture of H-20 and H-23 (1\%), $150 \mathrm{ml} /$ day of $\mathrm{H}-20$ and $\mathrm{H}-23(3 \%)$, and $250 \mathrm{ml} /$ day of $\mathrm{H}-20$ and $\mathrm{H}-23(5 \%)$. In the whole experimental periods, ruminal $\mathrm{pH}$ did not differ between treatments. However, the concentration of ruminal ammonia-N was increased in the $3 \%$ treatment relative to control and the $1 \%$ treatment at $1 \mathrm{hr}$ post-feeding $(\mathrm{p}<0.05)$. Avicelase and CMCase (carboxymethyl cellulase) activities in rumen fluid showed no significant difference among treatments. However, xylanase activity was higher in the $5 \%(119.49$, xylose $\mu \mathrm{mol} / \mathrm{ml} / \mathrm{min})$ than the $3 \%$ treatment $(71.02$, xylose $\mu \mathrm{mol} / \mathrm{ml} / \mathrm{min})$ at 0 hr post-feeding $(p<0.05)$. Concentrations of ruminal total VFA, acetate, propionate and valerate were unaffected by treatments, while butyrate was higher in the $3 \%$ treatment $(24.48 \mathrm{mM})$ than control $(15.71 \mathrm{mM})$ at $1 \mathrm{hr}$ post-feeding $(\mathrm{p}<0.05)$. Results indicate that minimum $3 \%$ inclusion of cellulolytic bacteria cultures improved ruminal fermentation, especially ammonia- $\mathrm{N}$ concentration and butyric acid production.
\end{abstract}

(Key words : Cellulolytic bacteria cultures, Hanwoo heifers, Ruminococcus flavefaciens, Fibrobactor succinogenes)

$$
\text { I. 서 론 }
$$

반추동물의 생산성을 향상시키기 위하여 많은 연구 가 진행되고 있다. 이를테면 중조(sodium bicarbonate)와 같은 완충제를 사용함으로써 반추위 $\mathrm{pH}$ 안정화와 섬 유소 소화능력을 향상시킬 수 있으며 (Santra 등, 2003), 모넨신과 같은 항생제를 이용하여 에너지 효율 을 개선시킬 수 있다(Wang 등, 2004). 그러나 완충제 의 첨가는 사료의 기호성을 떨어뜨려 사료 섭취량을 감소시키고(Muck 등, 1990), 모넨신은 유지방 감소현 상을 나타내는 등 부작용이 대두되고 있는 실정이다 (Symanowski 등, 1999; Phipps 등, 2000). 또한 이러한 화학제제 및 항생제의 사용은 식품의 안정성과 건강
에 대한 소비자의 인식의 변화로 국내에서 사용이 점 차 줄어들고 있으며, 새로운 천연물질을 이용한 미생 물제제(direct-fed microbial agents, DFM)의 개발이 시 도되고 있다.

$\mathrm{DFM}$ 의 반추동물에 대한 급여 효과는 반추위내 영 양공급과 반추위 미생물의 선택적 활성화에 있다고 볼 수 있다(Williams와 Newbold, 1990). 현재 상업적으 로 시판되는 $\mathrm{DFM}$ 은 섬유소분해효소(fibrolytic enzymes), 누룩곰팡이(Aspergillus oryzae), 젖산균 (Lactobacillus) 및 효모배양액 (yeast culture extracts) 등이 사용되고 있다. 반추위내 우점하고 있는 섬유소분해 박테리아는 실질적인 섬유소 분해 미생물 군집이라고 볼 수 있다 (Windham과 Akin, 1984). Fibrobacter succinogenes 및

Corresponding author: Chang-Hyun Kim, School of Animal Life and Environment Science, Hankyong National University, Anseong-Si, 456-749, Korea Tel: 031-670-5095, Fax: 031-676-5091, E-mail: kimch@hknu.ac.kr 
Ruminococcus flavefaciens 는 대표적인 반추위 섬유소 분해 박테리아로 알려져 있으며 (Hungate, 1966), 이들 은 대부분 불용성 기질인 사료입자에 붙어서 존재할 뿐만 아니라 (Kudo 등, 1987) cellulase와 hemicellulase 를 분비하는 기능을 가지고 있다(Bryant, 1973; Pettipher와 Latham, 1979; Forsberg 등, 1981; Greve 등, 1984; McDermid 등, 1990). 그러나 반추동물의 장내에 서식하고 있는 혐기 박테리아를 생산성 향상 목적으 로 투여한 연구는 많지 않으며, 현재까지 반추동물의 장내 미생물을 이용한 $\mathrm{DFM}$ 의 개발은 대부분 분리 동정에 머무르고 있는 실정이다.

따라서 본 연구는 실험실에서 순수분리 - 동정한 섬 유소 분해균인 Ruminococcus flavefaciens H-20 및 Fibrobactor succinogenes H-23의 혼합 배양액을 수준별 로 반추동물에 적용하였을 때 반추위발효와 섬유소분 해효소활성에 미치는 영향을 조사하여 반추동물의 생 산성 향상에 목적이 있다.

\section{․ 재료 및 방법}

\section{1. 액상 생균제 준비}

한경대학교 동물영양학 실험실에서 젖소의 반추위 로부터 분리한 섬유소 분해 박테리아 중 섬유소 분해 력이 강력한 균들을 $16 \mathrm{~s} \mathrm{rDNA}$ 분석을 통해 동정한 후, 그 중 분해력이 가장 높은 2종의 혐기성 박테리아 (Ruminococcus flavefaciens H-20, Fibrobacter succinogenes $\mathrm{H}-23)$ 를 공시하였다. 본 실험에서 접종용으로 이용될 각 균주는 Dehority's artificial(DA) medium (Dehority, 1967)에 24시간 배양하여 종균으로 사용하 였다. 접종용 배지는 H-20과 H-23 균주에 따라 DA medium에 탄수화물 공급원으로 cellulose (S-5504, Sigma, U.S.A) 또는 starch (S-9765, Sigma, Germany)를 각각 $0.2 \%$ 로 사용하였으며, 질소공급원은 두 균주 모두 casein을 $2 \%$ 로 사용하였다. 혐기적 방법으로 멸균된 배양액을 준비하여 시험용 $100 \mathrm{ml}$ serum bottle에 배지 를 준비하였다. 24시간 배양 시킨 배양액 $1 \mathrm{ml}$ 씩을 미 리 준비한 배지가 포함된 시험용 serum bottle에 접종 및 배양하였으며, 살아있는 균수를 Bryant와 Burkey (1953)가 사용한 anaerobic dilution solution을 사용하여 최확수법 (most probable number, $\mathrm{MPN}$ )으로 확인하였 다. 그 결과, 본 실험에 사용된 $\mathrm{H}-20$ 은 $2.3 \times 10^{7} \mathrm{cfu} / \mathrm{ml}$ 이었고 $\mathrm{H}-23$ 은 $9.3 \times 10^{7} \mathrm{cfu} / \mathrm{ml}$ 이었다.

\section{2. 공시가축 및 사양관리}

본 시험의 사양실험은 경기도 가축위생연구소 실험 동물 사육실에서 실시하였으며, 기타 분석은 한경대학 교 동물영양학 실험실에서 수행하였다. 공시가축은 반 추위 fistula가 장착된 12 개월령 한우 암소 4 두 (평균
Table 1. Ingredients and chemical composition of feedstuffs fed to Hanwoo heifers

\begin{tabular}{|c|c|c|}
\hline Ingredients & \multicolumn{2}{|c|}{$\%$ of $\mathrm{DM}$} \\
\hline Corn flake & \multicolumn{2}{|c|}{26.2} \\
\hline $\begin{array}{l}\text { Distillers dried grains } \\
\text { with solubles }\end{array}$ & \multicolumn{2}{|c|}{15.0} \\
\hline Wet corn gluten feed & \multicolumn{2}{|c|}{15.0} \\
\hline Copra meal & \multicolumn{2}{|c|}{11.5} \\
\hline Wheat bran & \multicolumn{2}{|c|}{8.9} \\
\hline Alfalfa & \multicolumn{2}{|c|}{8.0} \\
\hline Molasses & \multicolumn{2}{|c|}{6.0} \\
\hline Rapeseed meal & \multicolumn{2}{|c|}{5.0} \\
\hline Limestone & \multicolumn{2}{|c|}{1.85} \\
\hline Soybean meal & \multicolumn{2}{|c|}{1.2} \\
\hline Salt & \multicolumn{2}{|c|}{0.5} \\
\hline Mineral/Vitamin premix $^{1)}$ & \multicolumn{2}{|c|}{0.63} \\
\hline Calcium phosphate & \multicolumn{2}{|c|}{0.2} \\
\hline Essential oil & \multicolumn{2}{|c|}{0.02} \\
\hline Total & \multicolumn{2}{|c|}{100.00} \\
\hline Chemical composition & $\begin{array}{l}\text { Concent- } \\
\text { rate }\end{array}$ & $\begin{array}{c}\text { Hay } \\
\text { mixture }\end{array}$ \\
\hline Dry matter & 88.36 & 91.18 \\
\hline Crude protein & 17.23 & 9.99 \\
\hline Ether extract & 1.76 & 1.24 \\
\hline Crude fiber & 5.72 & 32.59 \\
\hline Crude ash & 6.87 & 9.05 \\
\hline Neutral detergent fiber & 28.92 & 68.28 \\
\hline Acid detergent fiber & 12.35 & 44.61 \\
\hline
\end{tabular}

${ }^{1)}$ Contained per kg diet: vitamin A, 18,000 IU; vitamin $\mathrm{D}_{3}, 3,600 \mathrm{IU}$; vitamin E, $15 \mathrm{IU}$; I, $1.5 \mathrm{mg} \mathrm{Fe}, 120 \mathrm{mg}$; $\mathrm{Mn}, 135 \mathrm{mg} ; \mathrm{Zn}, 135 \mathrm{mg} ; \mathrm{Cu}, 30 \mathrm{mg}$ and $\mathrm{Co}, 0.3 \mathrm{mg}$.

${ }^{2)}$ Contained tall fascue hay and ochardgrass hay.

체중 $221 \pm 7.5 \mathrm{~kg}$ )를 이용하였다. 시험 사료 (Table 1)의 급여는, 시판중인 육성우 농후사료 $2 \mathrm{~kg}$ 에 톨페스큐와 오차드그라스 혼합건초 $3 \mathrm{~kg}$ 을 1일 2회 (09:00, 17:00) 로 나누어 균등 급여하였다. 또한 음수와 미네랄 블록 은 사양시험 전 기간 동안 충분하게 제공 하였다. 전 체 사료의 섭취량 및 잔량 조사의 정확성을 위해 시 험사육사 stall에서 고정 사육하였으며, 기타 사양관리 는 시험 목장의 관행에 준하였다.

\section{3. 실험설계}

본 시험에서는 $\mathrm{DFM}$ 을 사용하지 않은 처리구(control), $1 \%(50 \mathrm{ml} /$ day, $\mathrm{H} 20+\mathrm{H} 23), 3 \%$ (150 ml/day, $\mathrm{H} 20+\mathrm{H} 23)$ 및 $5 \%(250 \mathrm{ml} /$ day, $\mathrm{H} 20+\mathrm{H} 23)$ 수준의 네 처리군으로 나누어, 사료 급여시 DFM을 반추위 cannula 안으로 직접 주입하여 실시하였다. 실험구 배치는 $4 \times 4$ Latin square design으로 설계하여 시험동물을 3주 동안 기초 사료에 적응시킨 후 시험을 실시하였으며, 각 period 
를 21일씩으로 각 기간 동안 $\mathrm{DFM}$ 을 처리별로 지속적 으로 투여하였다.

\section{4. 조사 항목 및 시험방법}

\section{(1) 사료성분 분석}

본 시험에 사용된 농후사료 및 건초의 일반성분은 $\mathrm{AOAC}$ (1995) 방법에 의하여 분석하였고, NDF (neutral detergent fiber) 및 $\mathrm{ADF}$ (acid detergent fiber)의 함량은 Van Soest 등 (1991)의 방법에 따라 분석하였다.

\section{(2) 시료 채취}

전체 시험 기간 15 주 동안 3 주간의 예비 기간을 거 쳐 본 실험 시작 후, 각 3주 period 마지막 일에 DFM 을 주입하여 $0,1,3$ 및 6 시간대별로 반추위액을 채 취하였다.

반추위액을 채취하기 위해 $50 \mathrm{ml}$ 의 conical tube에 4 겹의 gauze를 이용하여 위액을 채취하였다. 채취한 위 액은 추가발효를 방지하기 위해 ice box를 이용해 냉 장상태를 유지하며 신속히 본 대학으로 운반 후 분석 을 실시하였다.

\section{(3) 반추위 $\mathrm{pH}$ 측정}

각 시간대별 반추위액을 채취한 즉시 $\mathrm{pH}$ meter (Gmbh8603, Mettler-Toledo, Switzerland)를 이용하여 $\mathrm{pH}$ 를 측정하였다.

\section{(4) 암모니아질소}

반추위액내 암모니아질소 농도 측정은 Chaney와 Mabach (1962)의 방법으로 수행 하였다. 채취한 위액 을 $13,000 \mathrm{rpm}$ 에서 5 분 동안 원심분리를 하여 얻어진 상층액과 $\mathrm{NH}_{3}$ standard를 각각 $20 \mu \mathrm{l}$ 로 $20 \mathrm{ml}$ 시험관에 주입 후, phenol color reagent와 alkali-hypochlorite를 1 $\mathrm{ml}$ 씩 첨가하였다. 발색반응을 위해 $37^{\circ} \mathrm{C}$ 항온 수조에 서 15 분간 배양하여 반응을 시킨 후, 증류수를 $8 \mathrm{ml}$ 추가하여 희석하였다. 이후 spectrophotometer (V-530, Jasco, Japan)를 이용하여 $640 \mathrm{~nm}$ 에서 흡광도 (Optimal density)를 측정하여 암모니아질소 농도를 계산하였다.

\section{(5) 휘발성지방산 (volatile fatty acids, VFA) 분석}

반추위내 VFA는 Erwin 등 (1961)의 방법에 의해 수 행하였다. 각 시간대별 $\mathrm{pH}$ 가 측정된 반추위액을 microtube (MCT-175-C, Axygen, U.S.A)에 $1 \mathrm{ml}$ 씩 회수한 후 미생물의 작용을 정지하기 위해 $0.1 \mathrm{ml}$ 의 포화 $\mathrm{HgCl}_{2}$ 용액과 $25 \% \mathrm{HPO}_{3}$ 용액 $0.2 \mathrm{ml}$ 를 첨가하여 혼합 후 실온에서 30 분간 정치시켰다. 실온에서 정치시킨 배양액은 분석 전까지 $-20^{\circ} \mathrm{C}$ 의 냉동고에 보관하였다 가 micro centrifuge (5415R, Eppendorf, Germany)를 이 용하여 $13,000 \mathrm{rpm}$ 에서 10 분간 원심분리한 후 상층액 을 채취하였으며, gas chromatography (GC-2010, Shimadzu,
Japan)를 이용하여 VFA 표준용액을 기준으로 분석하 였다.

(6) 위액내 가수분해 효소의 활력

\section{1) 조효소액의 채취}

생균제 투여 후 $0,1,3$ 및 6 시간대의 반추위액을 채취하여 기질 입자를 제거하기 위해 $4^{\circ} \mathrm{C}$ 에서 micro centrifuge (5415R, Eppendorf, Germany)를 이용하여 13,000 $\mathrm{rpm}$ 에서 5 분간 원심분리한 후 최종 상층액을 extracellular enzyme activity 분석을 위한 조효소액으로 사 용하였다.

\section{2) 섬유소분해 효소활력 측정}

효소활력 측정을 위해 기질로 사용한 Avicel (11365, Fulka, U.S.A), carboxymethyl cellulose (C-4888, Sigma, U.S.A) 및 oat spelt xylan(X-0627, Sigma, U.S.A)을 $0.05 \mathrm{M}$ citrate buffer $(\mathrm{pH}$ 5.5) 및 potassium phosphate buffer $(\mathrm{pH}$ 7.0)와 혼합하여 기질용액을 제조하였다. 20 $\mathrm{ml}$ 시험관에 각각의 기질용액 $0.5 \mathrm{ml}$ 과 조효소액 0.5 $\mathrm{ml}$ 를 주입 후, $45^{\circ} \mathrm{C}$ 의 항온 수조에서 1 시간 동안 반응 시켰다. 반응 후 효소 반응을 정지시키기 위해 $100^{\circ} \mathrm{C}$ 에서 5 분 동안 진탕하였으며, DNS (dinitrosalicylic acid) 용액 $0.6 \mathrm{ml}$ 과 발색 반응시켜 spectrophotometer (V-530, Jasco, Japan)를 이용하여 $550 \mathrm{~nm}$ 에서 흡광도를 측정하 였다. 기질로부터 유리된 환원당의 양은 glucose 및 xylose를 standard로 하여 $\mu \mathrm{mol} / \mathrm{ml} / \mathrm{min}$ 단위로 환산하 였다.

\section{5. 통계처리}

본 실험에서 얻어진 결과들은 SAS package program (2003)의 GLM (Gereral Linear Model)을 이용하여 분산 분석을 실시하였으며, 처리평균간 차이는 Duncan 다 중검정법 (1955)에 의해 $95 \%$ 유의수준으로 하였다.

\section{III. 결과 및 고찰}

\section{1. $\mathrm{pH}$ 및 암모니아질소 농도}

12 개월령 한우 암소에 $\mathrm{DFM}$ 을 수준별 반추위내 투 여하여 시간대별 반추위 $\mathrm{pH}$ 및 암모니아질소 농도 변 화의 결과는 Table 2와 같다. 투여 후 시간에 따른 반 추위액의 $\mathrm{pH}$ 는 대조구와 $5 \%$ 처리구에서 3 시간까지 낮아지다가 6 시간에 서서히 회복된 반면, $1 \%$ 및 $3 \%$ 처리구는 6 시간까지 감소되는 경향을 보였다. 비록 처 리간 유의적 차이는 없었지만 $5 \%$ 처리구에서 다른 처 리구와 비교하여 3 시간에 가장 낮은 $\mathrm{pH}$ 를 나타냈다. 이 등 (2005)은 $\mathrm{pH}$ 감소 원인으로 액상 $\mathrm{DFM}$ 이 분비하 는 효소에 의한 기질분해로 생성된 총 휘발성지방산 생성 증가에 기인한 것으로 보고하였으며, 섬유소분해 효소를 조사료 및 $\mathrm{TMR}$ 에 혼합하여 젖소에 급여한 실 
Table 2. Effects of the inclusion of anaerobic rumen bacteria cultures on postprandial changes of ruminal $\mathrm{pH}$ and ammonia- $\mathrm{N}$ concentration in Hanwoo heifers

\begin{tabular}{|c|c|c|c|c|c|}
\hline \multirow{2}{*}{ Post-feeding } & \multicolumn{4}{|c|}{ Inclusion level (\%) } & \multirow{2}{*}{$\mathrm{SEM}^{1)}$} \\
\hline & 0 & 1 & 3 & 5 & \\
\hline $0 \mathrm{hr}$ & 675 & 6.74 & 6.65 & 6.62 & 0.039 \\
\hline $1 \mathrm{hr}$ & 6.64 & 6.54 & 6.44 & 6.41 & 0.066 \\
\hline $3 \mathrm{hr}$ & 6.37 & 6.32 & 6.33 & 6.17 & 0.066 \\
\hline $6 \mathrm{hr}$ & 6.42 & 6.24 & 6.28 & 6.28 & 0.068 \\
\hline & & $\cdots \mathrm{Nl}$ & dl & $\cdots \cdots$ & \\
\hline $0 \mathrm{hr}$ & 8.20 & 6.03 & 9.33 & 8.47 & 0.791 \\
\hline $1 \mathrm{hr}$ & $14.50^{\mathrm{b}}$ & $14.90^{\mathrm{b}}$ & $19.47^{\mathrm{a}}$ & $17.27^{\mathrm{ab}}$ & 0.825 \\
\hline $3 \mathrm{hr}$ & 17.87 & 14.97 & 18.80 & 17.40 & 1.109 \\
\hline $6 \mathrm{hr}$ & 6.37 & 8.33 & 10.30 & 9.03 & 0.973 \\
\hline
\end{tabular}

1) SEM, standard error of means.

a-b Means in the same row with different superscript differ significantly $(p<0.05)$.

험에서 처리구의 반추위내 $\mathrm{pH}$ 가 감소되었다(Kung 등, 2002). 본 실험에서도 생균제 투여에 따른 반추위내 혼합 미생물의 활성이 증가됨에 따라 사료의 발효가 반추위내에서 증가되어 $\mathrm{pH}$ 를 다소 감소시킨 것으로 생각된다.

반추위액내 암모니아 농도의 경우 대조구, 1 및 $5 \%$ 처리구에서 3시간까지 가장 높게 증가하다가 6시간에 감소하였다. $\mathrm{DFM}$ 투여 후 1 시간에 $3 \%$ 처리구에서 $19.47 \mathrm{mg} / \mathrm{dl}$ 로 $5 \%$ 처리구의 $17.27 \mathrm{mg} / \mathrm{dl}$ 와 차이는 없었 지만, 대조구 및 $1 \%$ 처리구의 14.5 및 $14.9 \mathrm{mg} / \mathrm{dl}$ 와 비 교하여 유의적으로 높은 농도를 보였다 $(\mathrm{p}<0.05)$. 이 (2006)에 의하면 반추위에서 순수 분리한 각각의 혐기 성 섬유소분해 박테리아 배양액을 이용하여 in vitro 발효 특성을 조사한 결과, 배양 후 72 시간까지 암모니 아질소 농도가 증가하였다는 결과로 보아 미생물 활 성의 증가에 기인하는 것으로 생각된다.

\section{2. 효소활력}

$\mathrm{DFM}$ 의 투여수준에 따른 반추위내 섬유소분해효소 활력의 결과는 Fig. 1 에 나타내었다. 비록 0 시간의 xylanase 농도를 제외하고 유의적인 차이가 없었지만 전체 처리구는 3 종류의 기질에 대해 사료섭취 후 1 시 간에 효소활력이 가장 증가하였으며, 그 중 $3 \%$ 처리 구에서 가장 높은 활력을 보였다. crystallized cellulose 인 Avicel을 분해하는 효소인 Avicelase ( $\beta-1,4$ exoglucanase)농도는 전체 처리구에서 낮게 나타났으며 $1 \%$ 처리구를 제외한 다른 처리구에서 1 시간에 가장 높게 증가하였다. CMCase는 DFM 첨가 수준별 유의 적 차이는 없었으며, oat spelt로부터 추출된 xylan을 기질로 하여 extracellular xylanase 활력을 조사한 결과 에서는 $5 \%$ 처리구에서 0 시간에 $119.49 \mu \mathrm{mol} / \mathrm{ml} / \mathrm{min}$ 로
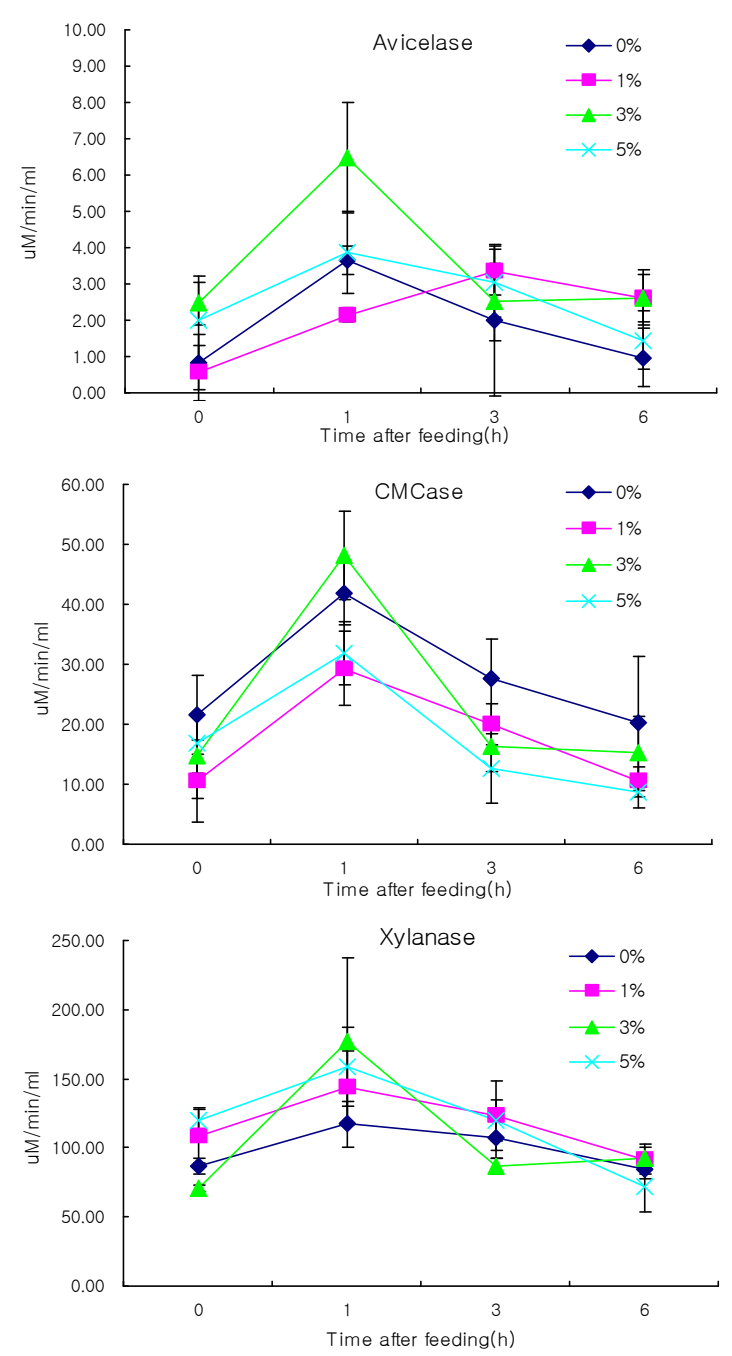

Fig. 1. Effects of the inclusion of anaerobic rumen bacteria cultures on postprandial change of ruminal enzyme activity $(\mu \mathrm{mol} / \mathrm{m} / / \mathrm{min})$ in Hanwoo heifers. 
$3 \%$ 처리구의 $72.02 \mu \mathrm{mol} / \mathrm{ml} / \mathrm{min}$ 와 비교하여 유의적으 로 높은 농도를 나타냈다 $(\mathrm{p}<0.05)$. 그러나 급여 후 시 간에 따른 수준별 유의적 차이는 나타나지 않았다.

Exogenous fibrolytic enzyme을 반추동물의 사료에 첨 가하여 급여하였을 때, 반추위내 섬유소분해효소 활성 에 따른 사료의 소화율 향상에 기인하여 유량 및 일 당증체량이 개선되는 것으로 보고되고 있다(Beau- chemin 등, $1995 ; 1997 ; 1999 ;$ McAllister 등, 1999; Kung 등, 2000). 그러나 Hristov 등 (2008)은 exogenous enzyme을 홀스타인 젖소에 공급시 반추위 내 amylase, CMCase 및 xylanase 활력은 증가하지 않았으며, 이는 공급한 효소의 활력이 반추위내 미생물 군집에 충분 한 영향을 미치지 못했기 때문이라고 보고하였다. 비 록 본 실험에서도 3 종류의 섬유소 기질에서 효소활력

Table 3. Effects of the inclusion of anaerobic rumen bacteria cultures on postprandial change of ruminal volatile fatty acid production(mM) in Hanwoo heifers

\begin{tabular}{|c|c|c|c|c|c|c|}
\hline \multirow{2}{*}{ Item } & \multirow{2}{*}{$\begin{array}{l}\text { Post-feeding } \\
\text { (hr) }\end{array}$} & \multicolumn{4}{|c|}{ Treatments } & \multirow{2}{*}{ SEM $^{1)}$} \\
\hline & & $0 \%$ & $1 \%$ & $3 \%$ & $5 \%$ & \\
\hline \multirow{4}{*}{ Acetic acid } & 0 & 85.09 & 79.02 & 79.76 & 76.87 & 3.644 \\
\hline & 1 & 96.97 & 103.40 & 106.34 & 101.44 & 5.254 \\
\hline & 3 & 97.07 & 108.23 & 98.16 & 106.26 & 4.926 \\
\hline & 6 & 91.57 & 105.31 & 101.73 & 97.96 & 4.594 \\
\hline \multirow{4}{*}{ Propionic acid } & 0 & 23.51 & 20.59 & 19.65 & 19.99 & 1.157 \\
\hline & 1 & 27.52 & 28.53 & 27.68 & 27.27 & 1.529 \\
\hline & 3 & 25.65 & 24.58 & 24.43 & 29.22 & 1.898 \\
\hline & 6 & 21.86 & 27.76 & 26.04 & 26.42 & 1.536 \\
\hline \multirow{4}{*}{ Butyric acid } & 0 & 14.15 & 13.05 & 14.35 & 12.15 & 0.727 \\
\hline & 1 & $15.71^{\mathrm{b}}$ & $21.32^{\mathrm{ab}}$ & $24.48^{\mathrm{a}}$ & $20.19^{\mathrm{ab}}$ & 1.271 \\
\hline & 3 & 18.79 & 22.14 & 19.98 & 20.74 & 1.411 \\
\hline & 6 & 17.42 & 21.04 & 21.23 & 18.96 & 1.333 \\
\hline \multirow{4}{*}{ Valeric acid } & 0 & 1.24 & 1.03 & 1.33 & 0.99 & 0.088 \\
\hline & 1 & 1.88 & 2.03 & 2.06 & 1.79 & 0.110 \\
\hline & 3 & 2.47 & 2.70 & 2.43 & 2.43 & 0.118 \\
\hline & 6 & 1.58 & 1.94 & 2.03 & 1.74 & 0.135 \\
\hline \multirow{4}{*}{ Iso-butyric acid } & 0 & 1.77 & 1.60 & 1.51 & 1.41 & 0.089 \\
\hline & 1 & 1.76 & 2.02 & 1.81 & 1.68 & 0.115 \\
\hline & 3 & 1.63 & 1.91 & 1.68 & 1.67 & 0.094 \\
\hline & 6 & 1.17 & 1.74 & 1.62 & 1.45 & 0.113 \\
\hline \multirow{4}{*}{ Iso-valeric acid } & 0 & 2.58 & 2.09 & 2.13 & 1.97 & 0.137 \\
\hline & 1 & 2.65 & 2.86 & 2.67 & 2.40 & 0.156 \\
\hline & 3 & 2.34 & 2.51 & 2.26 & 2.34 & 0.127 \\
\hline & 6 & 1.73 & 2.05 & 1.98 & 1.82 & 0.139 \\
\hline \multirow{4}{*}{$\begin{array}{c}\text { Acetic } \\
\text { acid/Propionic acid }\end{array}$} & 0 & 3.74 & 3.86 & 4.08 & 3.85 & 0.066 \\
\hline & 1 & 3.66 & 3.63 & 3.86 & 3.73 & 0.039 \\
\hline & 3 & 3.37 & 4.63 & 4.09 & 3.70 & 0.250 \\
\hline & 6 & 3.70 & 3.79 & 4.00 & 3.74 & 0.075 \\
\hline \multirow{4}{*}{ Total VFA } & 0 & 127.65 & 117.38 & 118.72 & 113.37 & 5.438 \\
\hline & 1 & 145.36 & 160.16 & 165.04 & 154.77 & 7.714 \\
\hline & 3 & 149.72 & 162.07 & 148.94 & 162.65 & 7.762 \\
\hline & 6 & 138.39 & 159.83 & 154.62 & 148.34 & 7.639 \\
\hline
\end{tabular}

1) SEM, standard error of means.

${ }^{\mathrm{a}-\mathrm{b}}$ Means in the same row with different superscript differ significantly $(\mathrm{p}<0.05)$. 
이 유의한 차이는 보이지 않았지만, $3 \%$ 처리구에서 $\mathrm{DFM}$ 투여 후 1 시간에 다른 처리구와 비교하여 수치 상으로 증가하는 경향을 나타내었다.

\section{3. 휘발성지방산}

액상 DFM의 투여수준에 따른 반추위내 VFA 농도 의 결과는 Table 3 에 나타내었다. 전체 처리구에 걸쳐 $\mathrm{DFM}$ 투여 후 1 시간 또는 3 시간에 가장 높게 증가한 후 6시간에 감소하는 경향을 나타냈다. Total VFA 농 도 및 acetic acid 농도는 1,3 및 $5 \%$ 처리구에서 0 시 간을 제외한 모든 시간에서 대조구와 비교하여 증가 된 농도를 보였으나, 처리에 따른 유의적 차이는 나타 나지 않았다. 비록 유의적 차이는 없었지만 반추위내 증가된 acetic acid 농도는 섬유소분해박테리아 군집 증가의 결과(Harrison 등, 1988)와 일치하며, butyric acid의 농도는 1시간에 $3 \%$ 처리구가 $24.48 \mathrm{mM}$ 을 나타 내어 대조구의 $15.71 \mathrm{mM}$ 과 유의적 차이를 나타냈다 $(\mathrm{p}<0.05)$. Hristov 등 $(2000)$ 은 탄수화물 분해효소(Exogenous polysaccharide-degrading enzyme)를 농후사료에 첨가하여 비육우에 급여한 결과, 대조구와 비교하여 반추위내 butyric acid의 농도가 증가했다고 보고하였다. Williams 와 Coleman(1992)은 반추위내 protozoa에 의해서 butyric acid가 증가하거나 감소한다고 보고하였으나, 본 연구에서는 섬유소분해 박테리아 배양액의 반추위 내 투여로 인해 반추위 미생물 개체군의 변화보다는 배양액내 효소들에 의한 영향에 기인했다고 생각된다. 이것은 이 (2006)의 보고에서 동일한 균주 H-20과 $\mathrm{H}-23$ 을 DA medium에서 2일간 순수 배양을 한 배양 상층액의 CMCase, Avicelase 및 xylanase의 활력이 각 각 73.9 와 $48.4 \mu \mathrm{mol} / \mathrm{ml} / \mathrm{min}, 10.9$ 와 $10.3 \mu \mathrm{mol} / \mathrm{ml} / \mathrm{min}$, 그리고 364.3 과 $60.16 \mu \mathrm{mol} / \mathrm{ml} / \mathrm{min}$ 이었다고 하여 이들 효소가 반추위내 투여되었을 때 영향을 미쳤을 것으 로 생각된다. 또한 사양 실험에 사용한 건초의 $\mathrm{ADF}$ 함량은 $44.61 \%$ 로 한국사양표준 사료성분표(농림부 농촌진흥청 축산기술연구소, 2002)의 볏짚 (44.12\%)과 비교하여 비슷한 수준이었다. 본 실험의 xylan을 기질 로 사용한 효소활력분석 결과, 대조구와 비교하여 DFM 투여 처리구에서 분해율이 높은 경향을 보였으 며 이는 DFM내 hemicellulase의 효과로 볼 수 있었다. 실험에 $\mathrm{ADF}$ 함량이 비교적 낮은 양질의 조사료를 사 용했다면 $\mathrm{DFM}$ 에 의한 반추위 발효에 더 큰 효과를 기대할 수 있을 것으로 생각된다.

이상의 결과에서 한우의 반추위 발효 효과를 향상 시키기 위해서는 $\mathrm{DFM}$ 을 투여하는 것이 긍정적 효과 를 줄 수 있음을 시사하며, 건물기준 최소 $3 \%$ 이상 사용하였을 때 반추위 발효에 유리할 것으로 판단된 다. 반추위 섬유소분해 박테리아 배양액을 DFM으로
사용하여 반추동물에 급여한 연구보고는 처음이며, 추 후 사료의 종류 및 배합비에 따른 추가 연구가 필요 할 것으로 판단된다.

\section{IV. 요 약}

본 연구는 홀스타인 젖소의 반추위에서 순수분리 및 동정된 섬유소 분해균인 Ruminococcus flavefaciens (H-20) 및 Fibrobactor succinogenes $(\mathrm{H}-23)$ 의 혼합 배양 액 (DFM)을 수준별로 반추동물에 적용하였을 때 반추 위발효와 섬유소분해효소 활성에 미치는 영향을 평가 하였다. 대사시험은 반추위 fistula가 장착된 12 개월령 한우 암소 4 두를 이용하여 $4 \times 4$ Latin square 방법으로 실시되었다. 모든 처리구는 기초사료로, 농후사료 $2 \mathrm{~kg}$ 에 톨페스큐와 오차드그라스의 혼합건초 $3 \mathrm{~kg}$ 을 1 일 2 회로 나누어 균등 급여하였으며, $\mathrm{DFM}$ 을 사용하지 않 은 처리구 (control), 기초사료를 포함하여 $1 \%(50 \mathrm{ml} / \mathrm{day}$, $\mathrm{H} 20+\mathrm{H} 23), \quad 3 \%(150 \mathrm{ml} /$ day, $\mathrm{H} 20+\mathrm{H} 23)$ 및 $5 \%(250$ $\mathrm{ml} / \mathrm{day}, \mathrm{H} 20+\mathrm{H} 23$ ) 수준의 네 처리군으로 나누어, 사 료 급여시 $\mathrm{DFM}$ 을 반추위 cannula 안으로 직접 주입하 여 실시하였다. 본 실험 결과 급여 후 모든 시간에서, 처리구는 반추위액내 $\mathrm{pH}$ 의 유의적 차이가 나타나지 않았으나, 반추위 암모니아 질소의 농도에서 $\mathrm{DFM}$ 투 여 후 1 시간에 $3 \%$ 처리구 $(19.47 \mathrm{mg} / \mathrm{dl})$ 는 $5 \%$ 처리구 $(17.27 \mathrm{mg} / \mathrm{dl})$ 와 차이는 없었지만, 대조구 및 $1 \%$ 처리 구 $(14.5$ 및 $14.9 \mathrm{mg} / \mathrm{dl})$ 와 비교하여 유의적으로 높은 농도를 보였다 $(\mathrm{p}<0.05)$. 섬유소분해효소활력은 전체적 으로 유의한 효과가 나타나지 않았으나, xylanase는 0 시간에 $5 \%$ 처리구 $(119.49 \mu \mathrm{mol} / \mathrm{ml} / \mathrm{min})$ 가 $3 \%$ 처리구 $(72.02 \mu \mathrm{mol} / \mathrm{ml} / \mathrm{min})$ 와 비교하여 유의적으로 높은 농도 를 보였다 $(\mathrm{p}<0.05)$. VFA 농도는 butyric acid에서 급여 후 1 시간에 대조구 $(15.71 \mathrm{mM})$ 와 비교하여 $3 \%$ 처리구 (24.48 mM)에서 유의적으로 높은 농도를 보였다 $(\mathrm{p}<$ 0.05). 이러한 결과로 미루어 보아 혐기성 섬유소분해 박테리아 배양액의 공급은 최소 $3 \%$ 이상에서 반추위 발효에 개선효과가 있는 것으로 나타났다.

$$
\mathrm{V} \text {. 사 사 }
$$

본 연구는 한경대학교 2008년도 학술연구조성비의 지원에 의한 결과로 연구비 지원에 감사드립니다.

\section{VI. 인 용 문 헌}

1. AOAC. 1995. Official Methods of Analysis. 16th ed. Association of Official Analytical Chemist, Washington, DC.

2. Beauchemin, K. A., Rode, L. M. and Sewalt, V. J. H. 1995. Fibrolytic enzymes increase fiber digestibility and 
growth rate of steers fed dry forages. Can. J. Anim. Sci. 75:641-644

3. Beauchemin, K. A., Jones, S. D. M., Rode, L. M. and Sewalt, V. J. H. 1997. Effects of fibrolytic enzyme in corn or barley diets on performance and carcass characteristics of feedlot cattle. Can. J. Anim. Sci. 77:645-653

4. Beauchemin, K. A., Rode, L. M. and Karren, D. 1999. Use of feed enzymes in feedlot finishing diets. Can. J. Anim. Sci. 79:243-246.

5. Bryant, M. P. and Burkey, L. A. 1953. Cultural methods and some characteristics of some of the more numberous groups of bacteria in the bovine rumen. J. Dairy Sci. 36:205-217.

6. Bryant, M. P. 1973. Nutritional requirements of predominant rumen cellulolytic bacteria. Fed. Proc. 32:18091813.

7. Chaney, A. L. and Marbach, E. P. 1962. Modified reagents for determination of urea and ammonia. Clin. Biochem. 8:130-132.

8. Dehority, B. A. and Scott, H. W. 1967. Extent of cellulose and hemicellulose digestion in various forage by pure cultures of rumen bacteria. J. Dairy Sci. 50:11361141.

9. Duncan, D. B. 1955. Multiple range and multiple F test. Biometrics. 11:1-42.

10. Erwin, E. S., Marco, S. J. and Emery, E. M. 1961. Volatile fatty acid analysis of blood and rumen fluid by gas chromatography. J. Dairy Sci. 44:1768-1771.

11. Forsberg, C. W., Beveridge, T. J. and Hellistroom, A. 1981. Cellulase and xylanase release from Bacteroides succinogenes and its importance in the rumen environment. Appl. Environ. Microbiol. 42:886-896.

12. Greve, L. C., Labavitch, J. M. and Hungate, R. E. 1984. a-L-arabinofuranosidase from Ruminococcus albus 8: Purification and possible role in hydrolysis of alfalfa cell wall. Appl. Environ. microbiol. 47:1135-1140.

13. Harrison, G. A., Hemken, R. W., Dawson, K. A., Harmon, R. J. and Barker, B. K. 1988. Influence of addition of yeast culture supplement to diets of lactating cows on ruminal fermentation and microbial population, J. Dairy Sci. 71:2967-2975.

14. Hristov, A. N., Basel, C. E., Melgar, A., Foley, A. E., Ropp, J. K., Hunt, C. W. and Tricarico, J. M. 2008. Effect of exogenous polysaccharide-degrading enzyme preparations on ruminal fermentation and digestibility of nutrients in dairy cows. Anim. Feed Sci. Technol. 145: 182-193.

15. Hristov, A. N., MCAllister, T. A. and Cheng, K. J. 2000. Intraruminal supplementation with increasing levels of exogenous polysaccharide-degrading enzymes: effects on nutrient digestion in cattle fed a barley grain diet. J. Anim. Sci. 78:477-487.

16. Hungate, R. E. 1966. The rumen and its microbes. Academic Press Inc. New York.

17. Kudo, H., Cheng, K. J. and Costerton, J. W. 1987a. Interactions between Treponema bryantii and cellulolytic bacteria in the in vitro degradation of straw cellulose. Can. J. Microbiol. 33:244-248.

18. Kudo, H., Cheng, K. J. and Costerton, J. W. $1987 \mathrm{~b}$. Electron microscopic study of the methylcellulose-mediated detachment of cellulolytic bacteria from cellulose fibers. Can. J. Microbiol. 33:267-272.

19. Kung, L., Jr., Treacher, R. J., Nauman, G. A., Smagala, A. M., Endres, K. M. and Cohen, M. A. 2000. The effect of treating forages with fibrolytic enzymes on its nutritive value and lactation performance of dairy cows. J. Dairy Sci. 83:115-122.

20. Kung, L., Jr., Cohen, M. A., Rode, L. M. and Treacher, R. J. 2002. The effect of fibrolytic enzymes sprayed onto forages and fed in a total mixed ratio to lactating dairy cows. J. Dairy Sci. 85:2396-2402.

21. McAllister, T. A., Oosting, S. J., Popp, J. D., Mir, Z., Yanke, L. J., Hristov, A. N., Treacher, R. J. and Cheng, K. -J. 1999. Effect of exogenous enzymes on digestibility of barley silage and growth performance of feedlot cattle. Can. J. Anim. Sci. 79:353-360.

22. McDermid, K., Mackenzie, C. R. and Forsberg, C. W. 1990. Esterase activities of Fibrobacter succinogenes subsp. succinogenes S85. Appl. Environ. Microbiol. 56: 127-132.

23. Muck, R. E., O'kiely, P. and Moran, J. 1990. Low pH grass silage. Teagasc Anim. Prod. Res. Rep., 1988-1989, pp. 77.

24. Pettipher, G. L. and Latham, M. J. 1979. Production of enzymes degrading plant cell walls and fermentation of cellobiose by Ruminococcus flavefaciens in batch and continuous culture. J. Gen. Microbiol. 110:29-38.

25. Phipps, R. H., Wilkinson, J. I. D., Jonker, L. J., Tarrant, M., Jones, A. K. and Hodge, A. 2000. Effect of monensin on milk production of Holstein-Friesian dairy cow. J. Dairy Sci. 83:2789-2794.

26. Santra, A., Chaturvedi, O. H., Tripathi, M. K., Kumar, R. and Karim, S. A. 2003. Effect of dietary sodium bicarbonate supplementation on fermentation characteristics and ciliate protozoal population in rumen of lambs. Small Ruminant Research 47:203-212.

27. SAS. 2003. SAS/STAT ${ }^{\circledR}$ Software for PC. SAS Institute Inc., Cary, NC, USA.

28. Symanowski, J. T., Green, H. B., Wagner, J. R., 
Wilkinson, J. I. D., Davies, J. S., Hirsmstedt, M. R., Allen, M. S., Block, E., Brennan, J. J., Head, H. H., Kennelly, J. J., Nielsen, J. N., Nocek, J. E., Van Der List, J. J. and Whitlow, L. W. 1999. Milk production and efficiency of cows fed monensin. J. Dairy Sci. 82 (Suppl 1):171.(Abstr.)

29. Van Soest, P. J., Roberts, J. B. and Lewis, B. A. 1991. Methods for dietary fiber, neutral detergent fiber, and non-starch polysaccharides in relation to animal nutrition. J. Dairy Sci. 74:3583-3597.

30. Wang, Y., Alexander, T. W. and McAllister, T. A. 2004. In vitro effects of Monensin and Tween 80 on ruminal fermentation of barley grain:barley silage-based diets for beef cattle. Animal Feed Sci. and Tech. 116:197-209.

31. Williams, A. G. and Coleman. 1992. The Rumen Protozoa Springer-Verlag Inc. New York, NY. pp. 441.

32. William, P. E. V. and Newbold, C. J. 1990. Rumen probiosis: The effects of novel microorganism on rumen fermentation and ruminant productivity. In: Haresign W. and Cole, F. J. A (Ed.) Recent Advances in Animal Nutrition. Butterworths, London. pp. 211-217.

33. Windham, W. R. and Akin, D. E. 1984. Rumen fungi and forage fiber degradation. Appl Environ Microbial. 48:473-476.

34. 농림부 - 농촌진흥청 축산기술연구소, 2002 , 한국사양표 준 (젖소). 상록사.

35. 이기영. 2006. 반추위로부터 분리된 혐기성 섬유소분해 박테리아의 혼합배양에 의한 발효 특성에 관한 연구. 한 경대학교 석사학위 논문.

36. 이성훈, 서인준. 2005. 반추가축영양에 있어서 액상미생 물제제의 첨가가 In Vitro 발효성상과 섬유소분해효소활 성에 미치는 영향. 한국동물자원과학회지 47:789-804.

(접수일자 : 2008. 7. 11. / 수정일자 : 2008. 12. 10. /

채택일자 : 2009. 2. 18.) 